\title{
Obraz czy figura? Uwagi o ołtarzu św. Stanisława Kostki w rzymskim kościele Sant'Andrea al Quirinale
}

zymski ołtarz memorialny Stanisława Kostki (1550-1568), polskiego świętego o międzynarodowym znaczeniu, stanowił szczególny w czasach kontrreformacji przykład formowania się nowożytnej nastawy. Usytuowany w jezuickim nowicjackim kościele Sant’Andrea al Quirinale, tworzy część nietypowego zespołu kultu Kostki koncentrującego się w dwóch odrębnych całościach - w kaplicy kościoła nowicjackiego oraz w tzw. celi w klasztorze. Stanisław Kostka, zmarły po krótkim pobycie w Rzymie (w Collegio Romano i nowicjacie na Monte Cavallo) i pochowany w kaplicy zakonnej, był pierwszym przedstawicielem nowicjatu zmarłym in odore sanctitatis, a jezuici starali się wykorzystać zaistniałą sytuację dla wykreowania świętego, idealnego patrona niższej formacji zakonnej ${ }^{1}$. Dlatego już w 1602 roku jako pierwszy w Towarzystwie Jezusowym wyróżniony został tytułem błogosławionego, wcześniej niż założyciel zakonu Ignacy Loyola $(1609)^{2}$. Od tego czasu aż do kanonizacji trwały starania o inscenizację świętego miejsca, w którym szczególnie byłby on uobecniany i uhonorowany. Czy można zatem w świetle źródeł archiwalnych i przekazów ikonograficznych pozwolić sobie na ustalenie roli ołtarza jako najważniejszego obiektu kultowego i liturgicznego stanowiącego ekspozycję wizerunku Kostki?

Pierwsza nastawa na podobieństwo ołtarza nad grobem błogosławionego w kościele nowicjackim Sant’Andrea na Monte Cavallo, przebudowanym przez jezuitę Giovanni Tristano, opisana została przez jezuitę Louise Richeôme (La peinture spirituelle, 1611). Była to podobna edikule struktura, wykonana $\mathrm{z}$ alabastru, zdobiona pilastrami, z gzymsami, architrawami i fryzami, złocona i pokryta reliefem, z motywem aniołów i girland ${ }^{3}$. Jej istnienie potwierdzał już wcześniej papież Paweł V w brewe vivae vocis oraculo z 20 sierpnia 1605 roku, podkreślając tym samym

\footnotetext{
Święty Stanisław Kostka 1928, k. V-XIV; Terhalle 2011, s. 102.

Koszutski 1882, t. 2, s. 91; Warszawski 1968, szp. 1369-1373; Terhalle 2011, s. 112.

BAIley 2003, s. 58; RicheÔME 1611, s. 47-48 (Voicy son Tableau, appendu en son sepulchre. Ie ne veux pas parler de la structure du sepulchre, ny de l'estoffe d'iceluy, passant la blacheur de l'alabastre, ou encore de la neige, ny parcourir les façons de ces pilastres, architraues, frizes, \& coronnements
} 


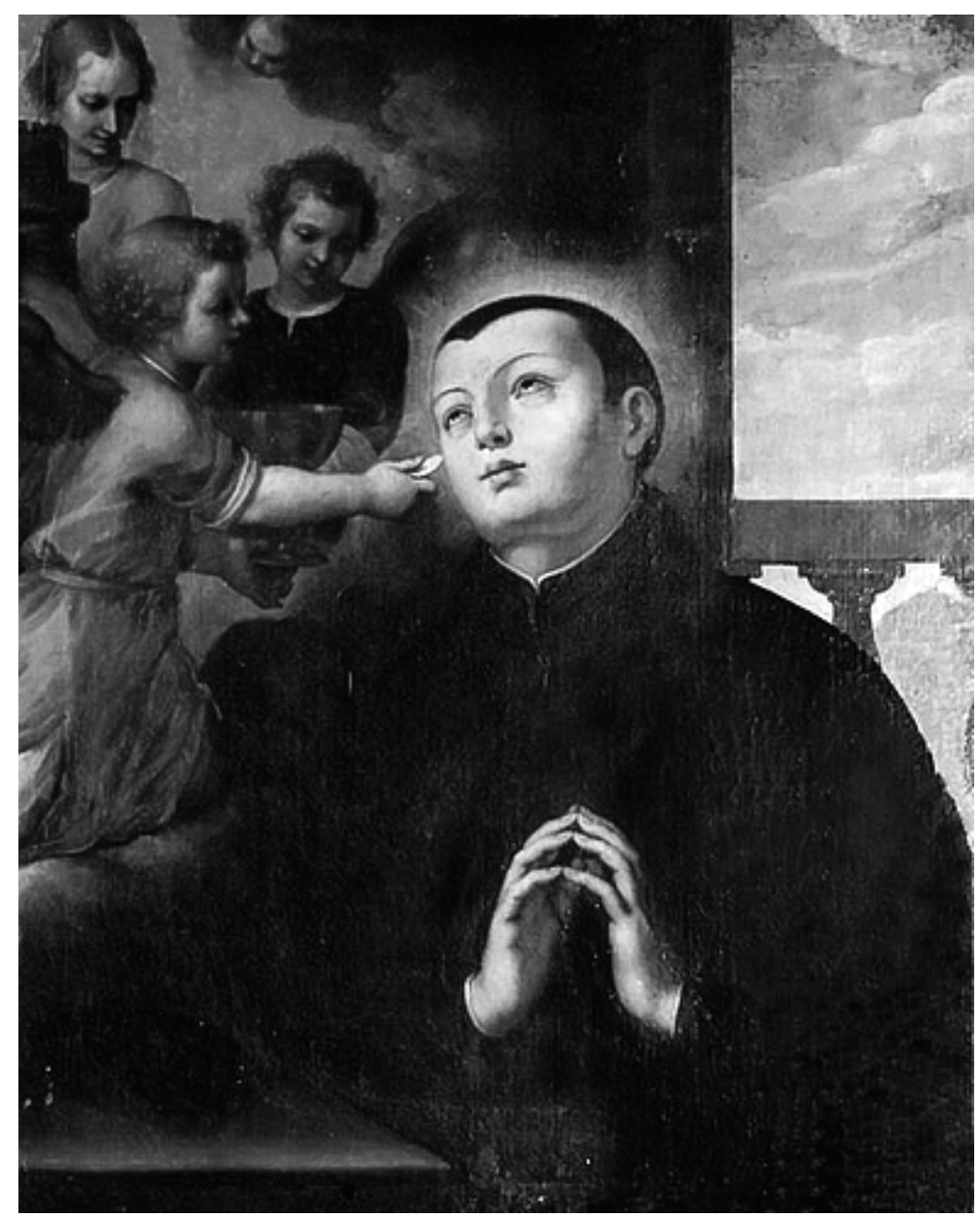

1. Wizerunek Stanisława Kostki („Komunia anielska”), malarz nieznany, ol. pł. przed rokiem 1600, Rzym, Sant'Andrea al Quirinale, fot. ze zbiorów autorki

znaczenie edikuli jako oprawy dla umieszczonego nad grobem obrazu Stanisława Kostki, oświetlonego, ozdobionego darami wotywnymi oraz kwiatami ${ }^{4}$. Ów obraz namalowany po śmierci młodzieńca, zapewne przed 1600 rokiem, odegrał kluczową rolę w początkach kultu jezuity (ilustr. 1). Jego zawieszenie przez polską delegację nad grobem Kostki w kaplicy nowicjatu jezuickiego 14 sierpnia 1605 roku przyjęto za początek oficjalnego kultu Polaka ${ }^{5}$. Obraz uznawany był przez współczesnych za vera effigies Stanisława Kostki, a pierwsi biografowie jezuiccy Francesco Sacchini oraz Piotr Skarga podkreślali, że „obraz jego w Rzymie, przy grobie jego postawiony,

embellis, \& enrichis de fin or, ny les ornements de ces festons, Anges, \& autres figures trauaillees de tres-riche matiere, \&e plus exquis artifice: votre oeil apperçoit tout cela sans l'oreille) oraz ARSI FG 1033, s. 37.

4 Ubaldini, t. 15, 1816, s. 293; Majkowski 1965, s. 25; Terhalle 2011, s. 101, przyp. 380.

5 Koszutski 1882, t. 2, s. 86-88; Bailey 2003, s. 41. 


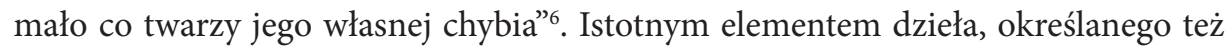
jako „Komunia anielska”, była wizja św. Barbary otoczonej z aniołami, którą przeżył młody szlachcic w domu luteranina Kimberkera w Wiedniu, kiedy przyjął sakrament eucharystii. Widoczny fragment pejzażu pozwalał - według L. Richeôme’a - na wyobrażenie miejsca compositio loci w myśl rozważań ignacjańskich?

Zmarłemu na malarię i pospiesznie pochowanemu osiemnastoletniemu nowicjuszowi, wyróżniającemu się religijnym charyzmatem i gorliwością, nie wykonano maski pośmiertnej. Jednak niemal wszyscy biografowie podkreślali wyraz jego twarzy „o kształcie raczej okrągłym”, chrakteryzującej się „cerą prawie śnieżno-białą, z lekko widocznym na policzkach rumieńcem”, otoczonej „włosami czarnymi, nieco płowiejącymi”. Najbardziej wymowne były jednak oczy „błyszczące, (...) wilgotne niekiedy i napełnione łzami”; na twarzy „znacznie wnętrzne jego nabożeństwo znać było” z „oczu wesołych, ale z nabożeństwa płaczliwych”. W tym wyidealizowanym portrecie, oddającym intymność przeżycia religijnego, wspomniany Richeôme dopatrywał się nawet anielskości oblicza młodzieńca, stwierdzając: „Myślałbyś portret anioła w ludzkim ciele” ${ }^{10}$. Struktura, której centrum stanowił obraz, określana jako sepulchrum, powielona została również w graficznych reprodukcjach: w pierwszej połowie XVII wieku (ilustr. 2), a później przez Jana Aleksandra Gorczyna w 1666 roku (ilustr. 3) ${ }^{11}$. Nastawa w formie edikuli, jak można się przekonać ze źródeł ikonograficznych, ozdobiona była precjozami i otoczona tabliczkami wotywnymi będącymi wyrazem kultu.

Z przekazów archiwalnych wiadomo, że do grobu swego błogosławionego brata stryjecznego księżna Anna z Kostków Ostrogska przesyłała „bogate noszenia i wotywy"12, srebrną lampę ofiarował biskup krakowski Bernard Maciejowski (1548$1608)^{13}$, kosztowne tkaniny kardynał protektor Polski Alessandro Peretti de Montalto ${ }^{14}$. Wota dziękczynne darowali biskup przemyski Maciej Pstrokoński (1533-1609), dziekan kapituły poznańskiej Fabian Konopacki (zm. 1619), Katarzyna z Kostków

\footnotetext{
SKARga 1936, s. 613; MAJKOWSKi 1965, s. 25.

BAILEY 2003, s. 58.

SACCHINI 1611, s. 52, 58; MAJKOWSKi 1965, s. 25.

9 Majkowski 1965, s. 26 (wg: J. Zuchowski, Nowy Patron Polski, Błogosławiony Stanisław Kostka Polak pismami...ks Piotra Skargi Societatis Iesu y inszych poważnych Pisarzów dostatecznie wykonterfektowany, Kraków 1611).

10 Richeome 1611, s. 49; BAiley 2003, s. 58.

11 Święty Stanisław Kostka 1928, k. LXXIV; wg napisu: SEPVLCHRVM BEATI STANISLAI KOSTKA SOC. IESV A NATIONE POLONA/ ROMAE IN TEMPLO S. ANDREA ERECTVM ANNO MDCV POST EXPOSITAM IN EO PUBLICE EJUSDEM BEATI IMAGINEM CV(M) VOTIVIS TABELIS ET LAMPADES PAVLI V PONT. MAX. AVTHORITATE.

12 Oborski 1630, s. 60-61; Duryewski 1702, s. 74; JARoszewicz 1850, s. 99-103; KoszUtski 1882, t. 2, s. 146; Terhalle 2011, s. 102.

13 KOSZUTSKI 1882, t. 2, s. 33.

14 ARSI Rom. 162, II, s. 263; BAILEY 2003, s. 57-58.
} 

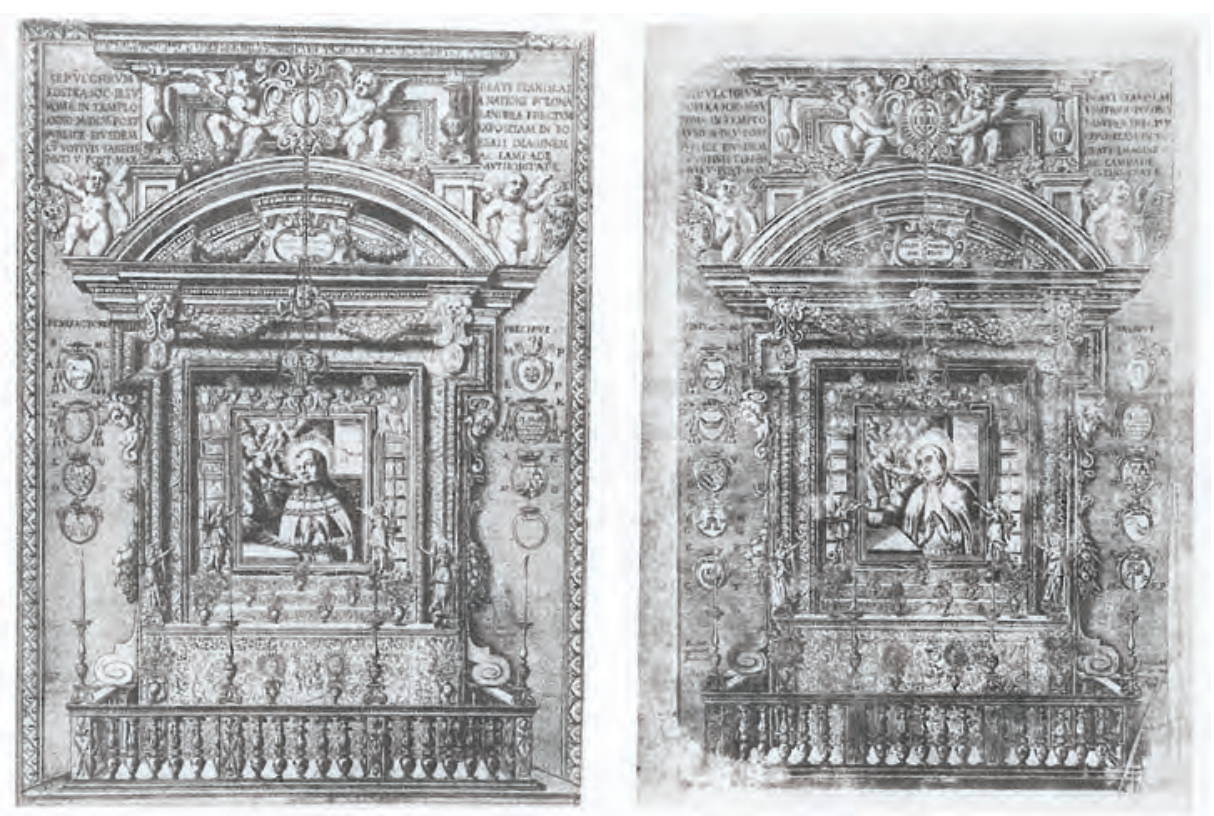

2-3. Sepulchrum Stanisława Kostki (dwie wersje), z pocz. XVII w. i wg ryciny J. A. Gorczyna (1666) fot. wg. Święty Stanisław Kostka, 1928, k. LXXIV

wraz z mężem Janem Stanisławem Wapowskim oraz królewicz Władysław Waza ${ }^{15}$. Darów było tak dużo, że jezuici, dbając o estetykę miejsca, przenosili je do zakrystiii ${ }^{16}$.

Problematyczne pozostaje autorstwo omawianej struktury wykonanej ok. 1605 roku, o pewnych podobieństwach ze współczesnymi realizacjami ołtarzowymi projektu Carlo Maderno ${ }^{17}$. Trudno jest równocześnie dokładnie sprecyzować, od kiedy grób Kostki uzyskał charakter ołtarza obdarzonego benedykcją. Jednak roczne sprawozdanie nowicjatu z 1650 roku wymienia obok trzech ołtarzy również czwarty:

I jest tam także jeszcze inny ołtarz, który bogato zdobiony jest pozłacanymi sztukateriami oraz wizerunkiem (obrazem) bł. Stanisława Kostki, pod którym znajduje się jego ciało w ołowianej skrzynce zamkniętej elementami z pozłacanego żelaza oraz wiele srebrnych wot i podziękowań do ołtarza jest dodana, przed którym stale płoną srebrne świeczniki ${ }^{18}$.

Status grobu-ołtarza uległ zmianie po wzniesieniu nowego kościoła. Już w pierwszym projekcie kościoła Sant’Andrea, autorstwa Giovanniego Lorenzo Berniniego, planowany był ołtarz dedykowany Stanisławowi Kostce w jednym z naroży

\footnotetext{
15 Koszutski 1882, t. 2 , s. $33,80-81,84$.

16 Tamże, s. 84, 88.

17 Terhalle 2011, s. 26; wskazać należy ołtarz projektu Carlo Maderno w kaplicy Aldobrandini przy kościele Santa Maria sopra Minerva (1605) oraz ołtarz główny w kościele Santa Maria della Pace (1611-1614) o charakterystycznej płaskości i linearności schematu.

18 Terhalle 2011, s. 117, przyp. 453; BAV Vat. lat. 11886, fol. 533v. (1669).
} 


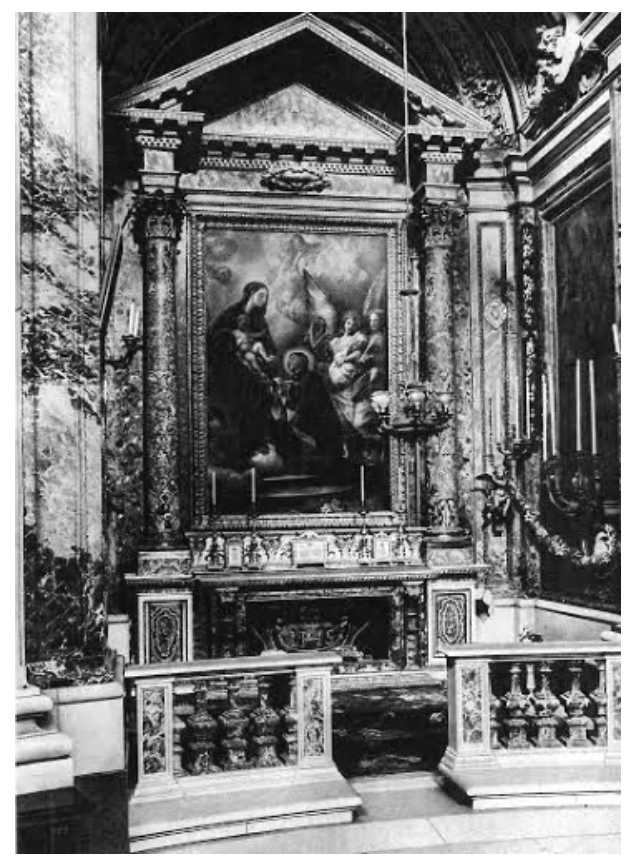

4. Ołtarz św. Stanisława Kostki, przed 1670, Rzym, Sant'Andrea al Quirinale (stan ok. 1928), fot. wg. Święty Stanisław Kostka, 1928, k. V.

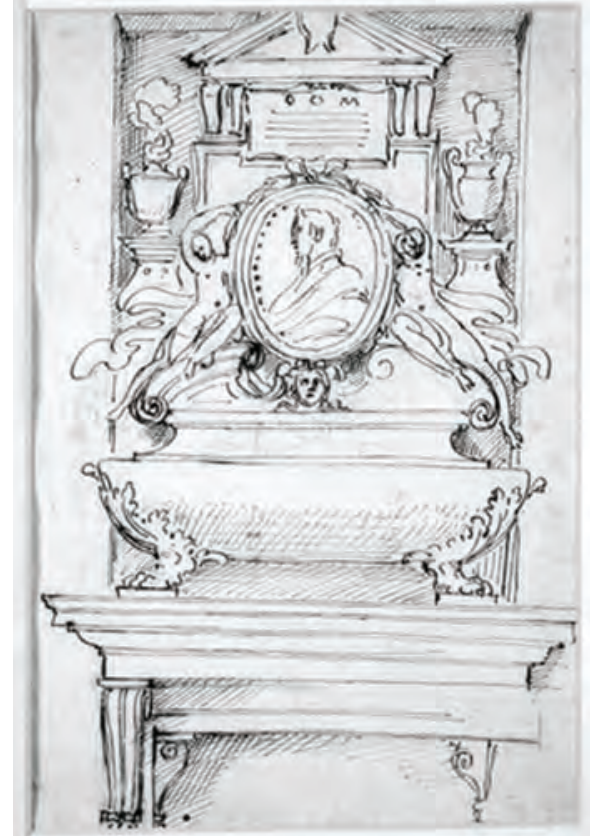

5. Projekt sarkofagu Stanisława Kostki, Carlo Maratta, szkic, Royal Collection Trust Buckingham Palace, fot. www.royalcollection.org.uk Her Majesty Queen Elizabeth II

pentagonalnej budowli, równorzędny z ołtarzami Ignacego Loyoli i Franciszka Ksawerego ${ }^{19}$. W owalnej przestrzeni nowego kościoła nowicjackiego, projektu Berniniego (1658-1661), Kostce poświęcono kaplicę boczną w grubości muru centralnej elipsy, obok wielkiego ołtarza w diagonalnej osi kościoła (ilustr. 4). W niej umieszczony został monumentalny, aczkolwiek skromny ołtarz, jednoosiowy, w kształcie edikuli ujętej kompozytowymi kolumnami ${ }^{20}$.

Znacznie większym problemem stało się wykonanie stosownego obrazu ołtarzowego $\mathrm{z}$ wizerunkiem błogosławionego nowicjusza $\mathrm{w}$ związku $\mathrm{z}$ kolejnymi etapami upubliczniania jego kultu. Dzięki zachowanej dokumentacji w archiwum zakonnym posiadamy wiadomości o problemach z obrazem podczas pierwszej mszy i oficjum bł. Stanisława, ustalonym przez Klemensa X w 1670 roku $^{21}$, który określił też dies festus błogosławionego. W dokumentach jezuickich w 1669 roku jest mowa nie o „ołtarzu” ozdobionym portretem przedstawiającym „Komunię anielską" świętego, lecz o innym obrazie wskazującym na cud zaczerpnięty z jego vitae - objawienie się Matki Boskiej ${ }^{22}$.

\footnotetext{
19 MARder 1998, s. 197.

20 Chrzanowski/Kornecki 1994, s. 48.

21 Sommervogel 1932, s. 1475; Terhalle 2011, s. 110.

22 Terhalle 2011, s. 116, przyp. 450. (...ha un guadretto con la sua Imagine con l'apparzione della Beatis[s]ima Vergine).
} 


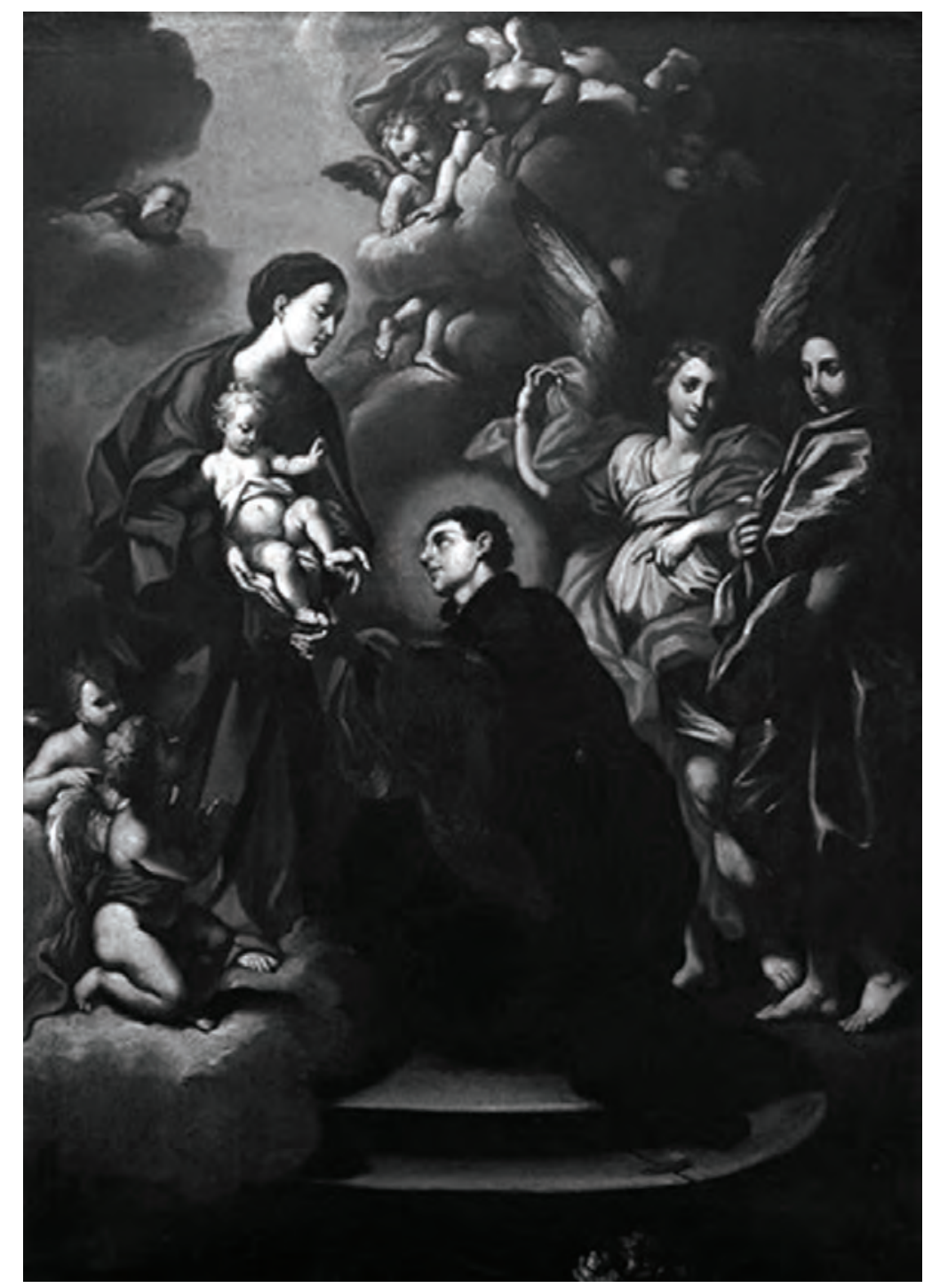

6. Wizja św. Stanisława Kostki, C. Maratta, ol. pł., ok. 1679-1687, obraz w ołtarzu kaplicy Stanisława Kostki, Rzym, Sant'Andrea al Quirinale, fot. ze zbiorów autorki

Wieczorem 11 listopada 1670 roku, jak informują źródła archiwalne, jezuici przenieśli sacre osse ze starego do nowego kościoła, a następnego dnia nastąpiła translokacja jego "grobu/ołtarza/obrazu”, który został wystawiony w nieukończonym jeszcze wnętrzu nowej kaplicy ${ }^{23}$. Dzień później odprawiono pierwsze oficjum, wcześniej zastępując dotychczasowy obraz nowym, nieukończonym (!) jeszcze

23 Terhalle 2011, s. 117, przyp. 451; ARSI, FG 1017, s. 83 [1670]. (Adi detto [11 november 1670] si e transportato il corpo del $n$ [ost] ro B[eato] Stanislao Kostka dalla Chiesa vecchia di S. Andrea alla nuova, e si riposto sotto l'altar della $p[\mathrm{r}]$ ima Capella a man dritta dell Altar maggiore. La translatione fu fatta ad un ora di notte, fu portata la cassa di legna, in cui riposano queste sacre osse...). 
dziełem Carluccia, to jest Carla Maratty, który go właśnie wykonywał na polecenie kardynała Antonio Barberiniego ${ }^{24}$. W tej bezprecedensowej sytuacji nieukończony, lecz „poprawny” obraz sławnego malarza tworzył decorum świątecznego dnia bardziej stosownie niż wystawiony już wcześniej obraz Kostki o zapewne o tożsamej ikonografii. Po uroczystości, wieczorem kolejnego dnia, wymagający ukończenia obraz jezuici oddali malarzowi i ponownie wprawili poprzedni ${ }^{25}$.

Jaki wizerunek sankcjonujący kult Kostki był zatem pożądany dla nowo wzniesionego ołtarza? Interesujące pozostają zachowane świadectwa ikonograficzne, potwierdzające dążenie do kształtowania się nowej, właściwej dla ołtarza ikonografii jezuickiego nowicjusza. Przechowywany w Allen Memorial Art Museum - Oberlin College (Ohio, USA) dużych rozmiarów przygotowawczy szkic $(47,3 \times 33,1 \mathrm{~cm})$ Mistyczna komunia bt. Stanisława, datowany na ok. 1679 rok (ilustr. 7), określony przez Williama Hooda jako rodzaj pensiero, przypisany został Ciro Ferriemu (1633-1689), współpracownikowi Pietro da Cortony, zaangażowanemu do dekoracji kościoła del Gesu przez Pietro Paolo Olivę $\mathrm{S}^{26}$. Nerwowy wirtuozowski rysunek wydobywa ekspresję centralnie usytuowanej grupy postaci i mistyczne doznania młodzieńca osuwającego się w ekstatycznym omdleniu, podtrzymywanego przez anioły wobec hostii $\mathrm{w}$ promienistej monstrancji. Jak przyjęto $\mathrm{w}$ literaturze, przedstawia również epizod upamiętniający wizję młodzieńca w Wiedniu, nieobecna jest jednak św. Barbara, która występowała w najstarszych graficznych wizerunkach Kostki z początku wieku XVII ${ }^{27}$. Wydaje się jednak, że kompozycja Ferriego odbiega od wątku biograficznego na rzecz uniwersalnej ikonografii wizji eucharystycznej i przypomina bardziej Ekstazęśw. Katarzyny Sieneńskiej Sodomy z bazyliki w Sienie. Szkic przygotowawczy Ferriego, podkreślający pobożność eucharystyczną, tożsamy znaczeniowo ze starszym wizerunkiem Kostki zawierającym w górnym rogu „komunię anielską", został prawdopodobnie odrzucony, choć wydawałoby się, że była to najlepsza tematycznie opcja, odpowiednia dla ołtarza - miejsca sprawowania eucharystii. Czy kryterium aksjologii wartości obrazu stanowił zatem przykład pasywnej, a nie aktywnej strony pobożności Kostki? Jak zauważył W. Hood, wybór ten nastąpił pomimo powszechnej znajomości ryciny Schelte’a a Bolswerta ukazującej bł. Stanisława aktywnie uczestniczącego w liturgii adoracji Najświętszego Sakramentu ${ }^{28}$.

$\mathrm{Na}$ eksperymentowanie $\mathrm{z}$ tematem wizji maryjnej jezuickiego nowicjusza wskazują liczne studia tego tematu autorstwa Carla Maratty. Potwierdza to nieopublikowany dotychczas obraz Principe dell Academia (lub jego kopia) przechowywany

\footnotetext{
24 Terhalle 2011, s. 117, przyp. 452; ARSI FG 1017 [1670], s. 85-86 (Nella Capella del B[eato] ai primi vespri si e posto il quadro del $B$ [eato] che stava nella Chiesa vecchia; La sera ci si pose il quadro che ne fa Carluccio [Carlo Maratta] del S[ign] or Card[ina]l Ant[oni]o [Barberini]benche non ancora finito, e ei si tenne tutt'il giorno segnente, e la sera ci si ripose l'altro nostro).

25 Terhalle 2011, s. 117.

26 Hood 1979/80, s. 26-49; De Angelis 2003, s. 113.

27 Hood 1979/80, s. 26-49.

28 Święty Stanisław Kostka 1928, k. LXXIV. O aspektach ikonografii św. Stanisława Kostki, zob. KöNIG-NoRDHOFF 1982, s. 96-100, 233, 259.
} 


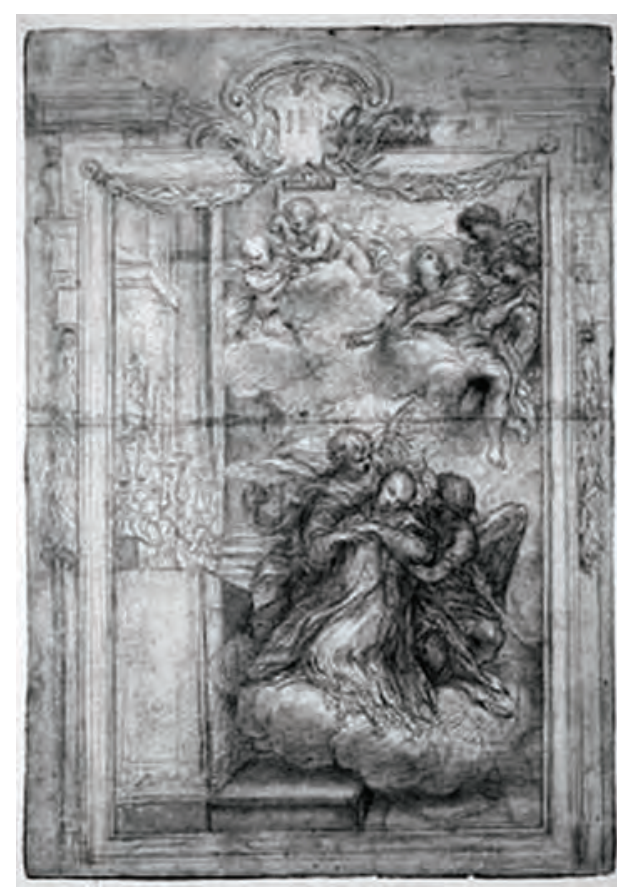

7. Mistyczna komunia bł. Stanisława Kostki, Ciro Ferri, szkic, ok. 1679, Allen Memorial Art Museum, Oberlin, fot. wg Hood 1979/1980, s. 27 w Royal Collection Trust Buckingham Palace w Londynie, przedstawiający wizję św. Stanisława Kostki, przypisywany rzymskiemu malarzowi, datowa-

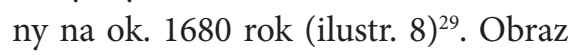
$\mathrm{w}$ formie leżącego prostokąta ukazuje przeciwlegle usytuowane sylwetki młodzieńca trzymającego Dzieciątko i unoszącą się na obłokach Marię podtrzymywaną przez anioły. Dla powstania tej kompozycji nie bez znaczenia był zapewne jeden $\mathrm{z}$ epizodów w rycinie Icones et miracula sanctorum Poloniae Petera Overadta (1605) ukazujący Marię podającą Dzieciątko choremu Kostce $^{30}$. O wizji jako przedmiocie studiów Carlo Maratty świadczy szkic w Royal Collection Trust Buckingham Palace, wskazany przez już Hooda ${ }^{31}$ (ilustr. 9). W rozbudowanym przedstawieniu Wizji św. Stanisława Kostki rzymski eklektyk zainspirował się prawdopodobnie najstarszym samodzielnym przedstawieniem tego tematu - ryciną projektu Antonio Circignaniego, zwanego Pomarancio, wykonaną w warsztacie Johanna Friedricha Greutera w 1619 roku, dedykowaną generałowi zakonu Muzio Vitelleschiemu (ilustr. 10) ${ }^{32}$. Malarz ostatecznie nie ukazał indywidualnego odczucia religijnego znanego w teologii jako incendium amoris ${ }^{33}$, lecz skoncentrował się na drugiej wizji z domu Kimberkera, tj. objawieniu się Matki Boskiej, będącej przyczyną wyzdrowienia Kostki i podjęcia życiowego powołania. Dzięki łasce Marii powierzającej młodzieńcowi Jezusa i jej poleceniu wstąpił on do zakonu jezuitów. Maratta w ostatecznej wersji obrazu (nota bene nawiązującej do Wizji św. Franciszka Ksawerego Gerarda Seghersa dla kościoła Jezuitów w Antwerpii, znanego z ryciny Paula Pontiusa, 1629), datowanej na lata 1679-1687, w diagonalnej kompozycji zachowuje jedynie istotę zdarzenia, odchodząc tym od charakteru rodzajowego, nieodpowiadającego wymaganiom ołtarzowego obrazu. Tzw. wizja wiedeńska przemienia się w glorię Stanisława Kostki, moment duchowego poznania, nasuwając obserwatorowi

29 Zob. Royall Collection; obraz włączony został do kolekcji królewskiej przez Fryderyka, księcia Walii, w 1750 roku.

30 KNAPIŃsKi 1999, s. 547, ilustr. 719.

31 Zob. Royal Collection; Hood 1979/80, s. 40, ilustr. 10.

32 Święty Stanisław Kostka 1928, k. LXXIX; BeLL 2009, s. 500-502.

33 Cereri 1994, s. 54. 


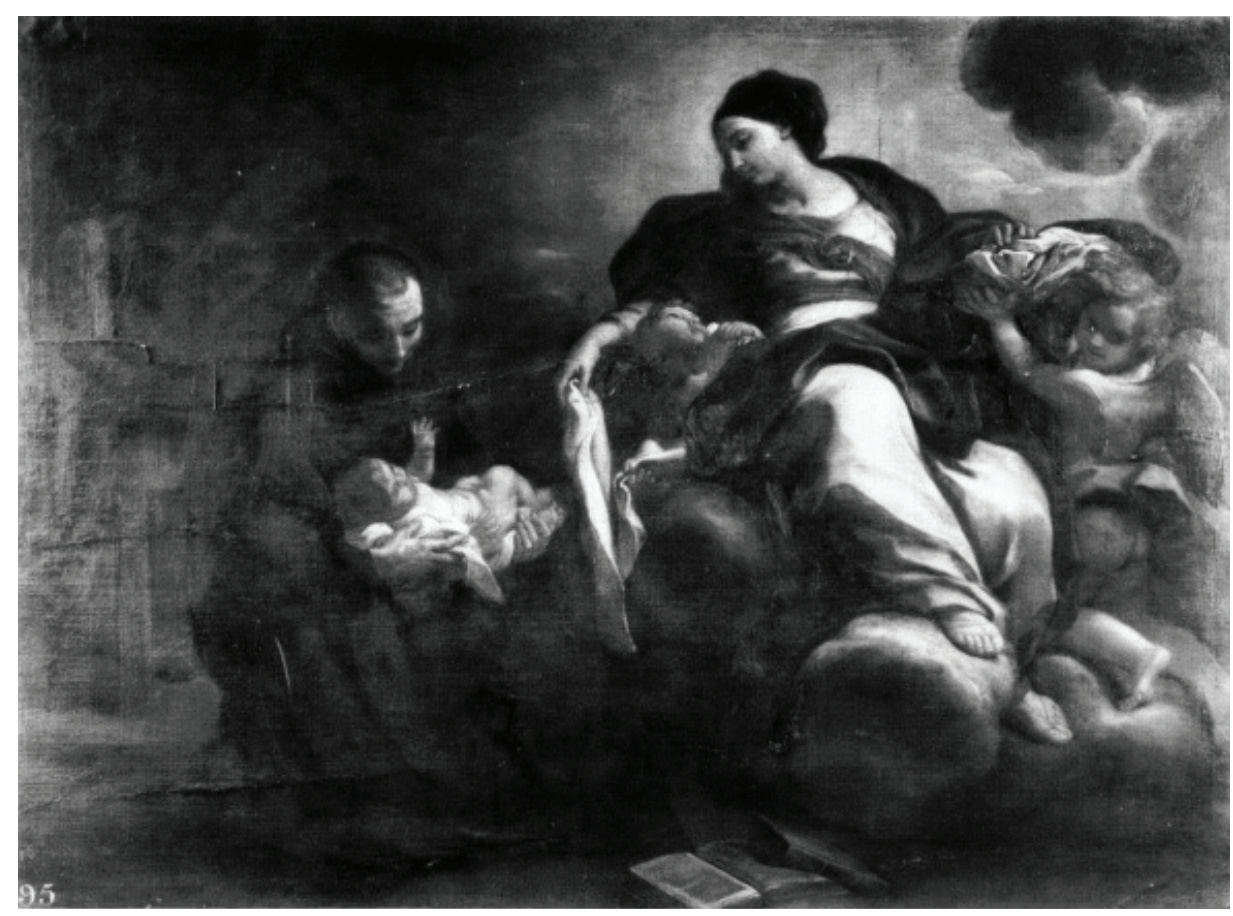

8. Wizja św. Stanisława Kostki, C. Maratta (kopia?), ol. pł., ok. 1680, Royal Collection Trust Buckingham Palace, fot. www.royalcollection.org.uk Her Majesty Queen Elizabeth II

myśl, że rzecz dzieje się raczej w niebie niż na ziemi ${ }^{34}$. Tym samym podnosi rolę konkretnego wymiaru powołania, wskazanego jako wzór dla nowicjuszy (ilustr. 6).

Kolejna modyfikacja ołtarza stała się przedmiotem ważnej dyskusji pomiędzy rzeźbiarzem, francuskim ekspatriantem Pierre’em Legrosem, a grupą wysokich rangą przedstawicieli Towarzystwa Jezusowego (Tirso Gonzales), zapewne w związku z planowaną kanonizacją jezuity. Jej przedmiotem stała się statua Stanisława Kostki autorstwa Legrosa ukończona w 1703 roku i przeznaczona dla tzw. celi (capellette), pomieszczenia w budynku nowicjatu, w którym prawdopodobnie Kostka zakończył życie ${ }^{35}$. Umieszczenie statuy przyczyniło się do utworzenia drugiej odrębnej przestrzeni poświęconej kultowi Kostki, ukierunkowanej na celebrację jego konania. Celowi temu służyć miała idealizująca rzeźba umierającego młodzieńca z wizerunkiem Madonny w ręku wykonana $\mathrm{z}$ różnobarwnych marmurów, nawiązująca do berniniowskiego ars moriendi egzaltowanej mistyczki Ludoviki Albertoni. Rzeźba o teatralnej, melodramatycznej ekspresji przeznaczona była dla stosunkowo wąskiego, elitarnego grona odbiorców, którzy mieli dostęp do objętej klauzurą przestrzeni, gdzie zmarł młodociany zakonnik. W zachowanej korespondencji z 1713 roku pojawił się projekt przeniesienia figury z prywatnych pomieszczeń na ołtarz relikwiarzowy

\footnotetext{
34 Pagaczewski 1927, s. 42-45; Terhalle 2011, s. 429, 446, ilustr. 127.

35 Pagaczewski 1927, s. 7-12; Conforti 1977, s. 558-559; Engass 1976, s. 138-139; Levy 1997, s. 88 .
} 


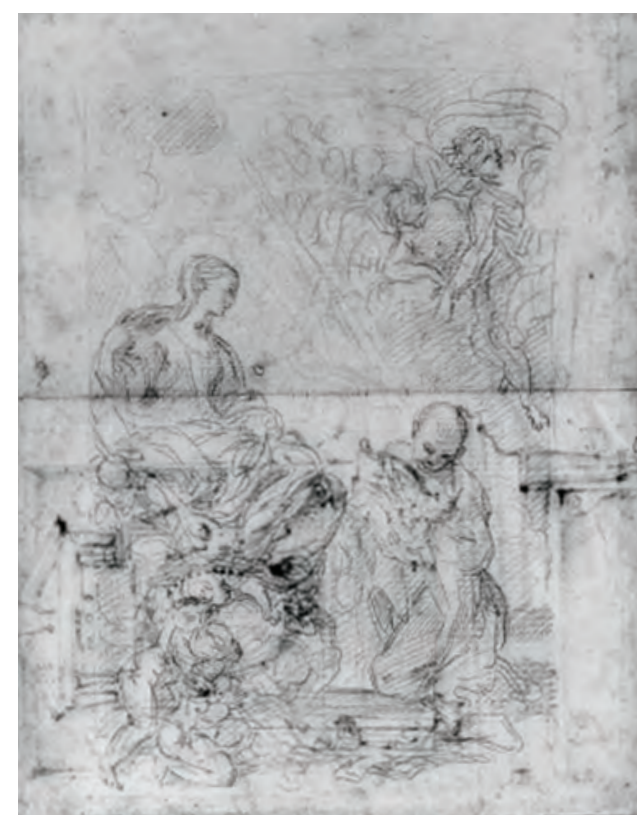

9. Wizja św. Stanisława Kostki, C. Maratta, szkic, ok. 1670, Royal Collection Trust Buckingham Palace. www.royalcollection.org.uk fot. wg Hood 1979/1980, s. 40 w kaplicy Kostki, tak aby była ona dostępna dla szerszego grona widzów. Legros proponował wykonanie polichromowanej stiukowej repliki statuy, która wypełniłaby wolne miejsce na ołtarzu. Z dokumentu wynika, że artysta sugerował, żeby wykonać niszę $\mathrm{w}$ miejscu, gdzie znajduje się obraz ołtarzowy, by następnie przenieść tam rzeźbę, aby mogła być przesłaniana obrazem tegoż błogosławionego, który można podnosić i opuszczać. W ten sposób kaplica Kostki uzyskałaby prestiż porównywany z kaplicą św. Ignacego Loyoli w kościele Il Gesú (1699), przy której wcześniej zatrudniony przez jezuitów Legros wykonał ponadnaturalnej wielkości statuę patriarchy Towarzystwa Jezusowego ${ }^{36}$.

W tej koncepcji ołtarz Stanisława Kostki wyróżniony mógł zostać, jak podkreślał artysta, na podobieństwo innych rzymskich ołtarzy grobowych, na przykład bł. Ludoviki Albertoni Berniniego (1671-1674) w kościele San Francesco a Ripa ${ }^{37}$. Zamiar poważnych ingerencji w strukturę ołtarza, celem lepszej ekspozycji figury i większego upublicznienia kultu poprzez bliższy kontakt z sensualną statuą młodzieńca, spotkał się z negatywnym stanowiskiem zakonu, który pomimo kilkakrotnych propozycji artysty nie przychylił się do jego wizji. Przeważyły, jak przypuszcza Levy, preferowane przez jezuitów względy estetyczne, spowodowane trudnościami z umieszczeniem naturalnej wielkości rzeźby młodzieńca w ołtarzu, a przede wszystkim zachowanie zamierzonej przez Berniniego jednolitości i harmonii wnętrza. Cztery kaplice zawierały ołtarze z identycznego marmuru oraz malowane obrazy, dlatego każda ingerencja zakłóciłaby pierwotny plan artysty ${ }^{38}$. Wszak już wcześniej, trzy lata po śmierci projektanta,

\footnotetext{
36 Levy 1997, s. 90, 108-109. ARSI FG. 865, fasc. 19 (Con tal' occasione Monsù Legros propose un suo pensiero, cioé: che N[o]stra Capella del Beato L.[?] facesse una nicchia, dove stá il quadro dell Altare, per poi transportarvi in essa la statua, che stà alle capellette: sopra di che sua Paternità il determine altro se il che d. Monsù esponesca q. to suo pensiero sopra un modello, che il med.o Monsù si esiti di fare à tutte sue spese; in maniera tale però, che possa l'altare star coperto $p$ [er] ordinario con il quadro dell' istesso Beato dà alzarsi, e calarsi, come si fà nella Capella di S. Ignazio al Giesù, affinche abbia l'uniformità con l'altre capelle; che piu sopra tal modello si sarebbe considerate meglio, se un tal pensiero sia dà abbracciarsi, ò no).

37 LeVy 1997, s. 96, 99, przyp. 33.

38 Tamże, s. 88, 91, 107 oraz MąCZyŃski 2003, s. 14, 29; HASkell 1955, s. 287, GonZAles-PalaCIOs 2007, s. 48.
} 
tj. ok. 1683 roku, pojawił się plan „nobilitacji” kaplicy poprzez pokrycie jej kosztownymi marmurami, aby - jako relikwiarzowa - wyróżniała się spośród pozostałych ${ }^{39}$. Być może z tego czasu pochodzi nieznany dotychczas projekt Carlo Maratty sarkofagu ozdobionego medalionem z popiersiem podtrzymywanym przez dwie figury (Royal Collection Trust Buckingham Palace) (ilustr. 5) ${ }^{40}$.

Jakie znaczenie miał więc poddawany modyfikacjom ołtarz Stanisława Kostki w rzymskim środowisku Towarzystwa Jezusowego? W wymianie poglądów dotyczących jego ostatecznego wyglądu kluczowe pozostaje stanowisko jezuitów w sprawie ekspozycji dzieła wzbudzającego pobożność lub „dewocyjnie nieefektywnego”. Umieszczona w kościele statua Legrosa pozbawiona patosu i silniejszych akcentów dramatycznych - jak utrzymywali jezuici - „wzbudzać miała mniej nabożnych uczuć

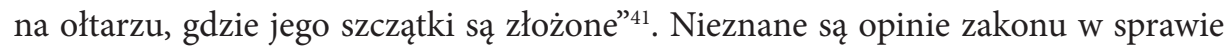
obrazu ołtarzowego w nowym berniniowskim kościele, jednakże liczne projekty i zmiany koncepcji płócien wskazują na dość długi proces formowania się ostatecznej wersji. Odnotowane jest natomiast stanowisko jezuitów w przypadku ołtarza w kaplicy św. Ignacego kościoła Il Gesú, kiedy miała miejsce wymiana podglądów odnośnie do wyboru statuy lub obrazu. Preferowane było jednak malarstwo, które zdecydowanie bardziej odpowiadało kontemplacyjnemu nastawieniu jezuitów, ponieważ ma "charakter narracyjny, i o wiele więcej, niż rzeźba zdolne jest wzbudzać religijne emocje" ${ }^{42}$. Był to element swoistego paragone w postrzeganiu sztuki.

Prezentacja najstarszego wizerunku Kostki w bogatej oprawie architektoniczno-rzeźbiarskiej odpowiadała w zasadzie formalno-estetycznej inscenizacji obrazów kultowych w Rzymie ok. 1600 roku $^{43}$. Wydaje się, że nie bez znaczenia był szerzący się kult założyciela oratorianów Filipa Neri (1515-1595) i jego wizerunek, który wkrótce po jego śmierci, w 1596 roku, jak informował Francesco Zazzara ${ }^{44}$, umieszczony został w ołtarzu. Był to obraz Niccolò Circignaniego, zwanego Pomarancio, ojca wspomnianego Antonio, upamiętniający wizję maryjną Filipa z 1594 roku, otoczony dekoracją w postaci aniołów wykonanych z pozłacanego stiuku. Preferencja wizji maryjnej utrzymana została w kolejnym kultowym wizerunku św. Filipa Neri w Rzymie przeznaczonym do ołtarza zawierającego relikwie w Santa Maria in Vallicella (Chiesa Nuova) wykonanym przez Guido Reniego w 1614 roku z okazji beatyfikacji założyciela oratorianów ${ }^{45}$. Celem obrazu ołtarzowego Kostki stawało się podkreślenie kultu maryjnego mającego priorytetowy charakter w jezuickiej

\footnotetext{
39 LeVy 1997, s. 91.

40 Royal Collection. Nabyty przez Jerzego III w roku 1762 jako część kolekcji kardynała Alessandro Albaniego; pierwszy raz odnotowany w inwentarzu Royal Collection inventory of c. 1810 (Inv. A, p. 107: ,V:M: \& a young Jesuit Saint. St. Stanislaus', szkic dwustronny, piórko, atrament). 


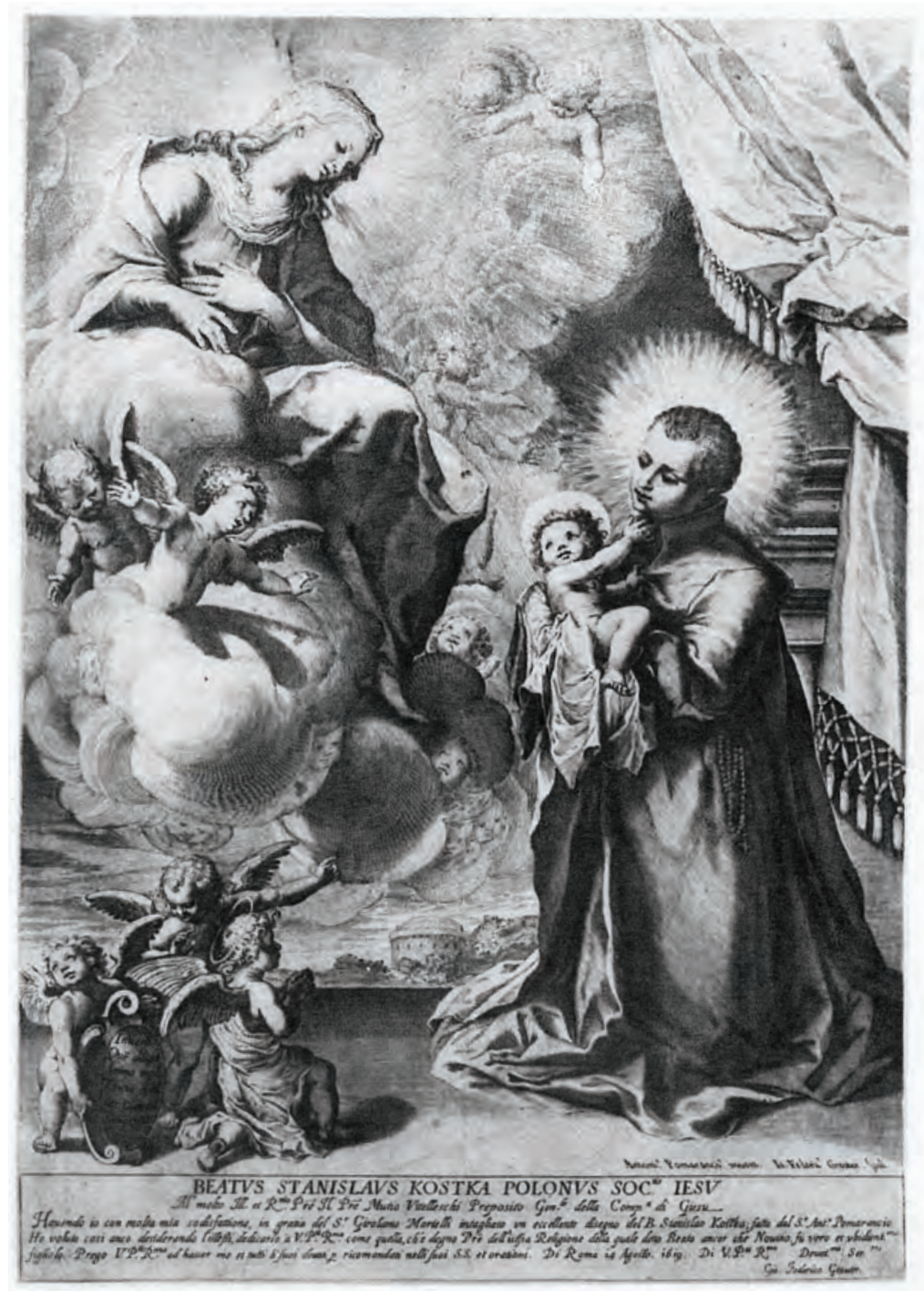

10. Wizja św. Stanisława Kostki, J.F. Greuter wg A. Circignari zw. Pomarancio, miedzioryt, 1619 fot. wg. Święty Stanisław Kostka, 1928, k. LXXIX

pobożności oraz intymnej emocji, której nie gwarantował ustalony w ikonografii przez P.P. Rubensa wizerunek Ignacego Loyoli jako triumfatora wiary i cudotwórcy oraz obrońcy Kościoła przed herezją (na obrazach z kościołach jezuickich w Antwerpii [1618-1619] oraz Genui [1619-1620]) ${ }^{46}$. Wizerunki Kostki wiązały się z ekspozycją uczuć młodzieńca zapewne w związku ze wzmożoną potrzebą afektywnej pobożności w zakonie jezuickim. Niewątpliwie istotne było odwołanie się do uświęconych tradycją wzorów Rubensa, "malarza ludzkich afektów”"47,

\footnotetext{
46 Tamże, s. 169-170, ilustr. 114 i 115.

47 SAUERLÄNDER 2011, s. 10.
} 


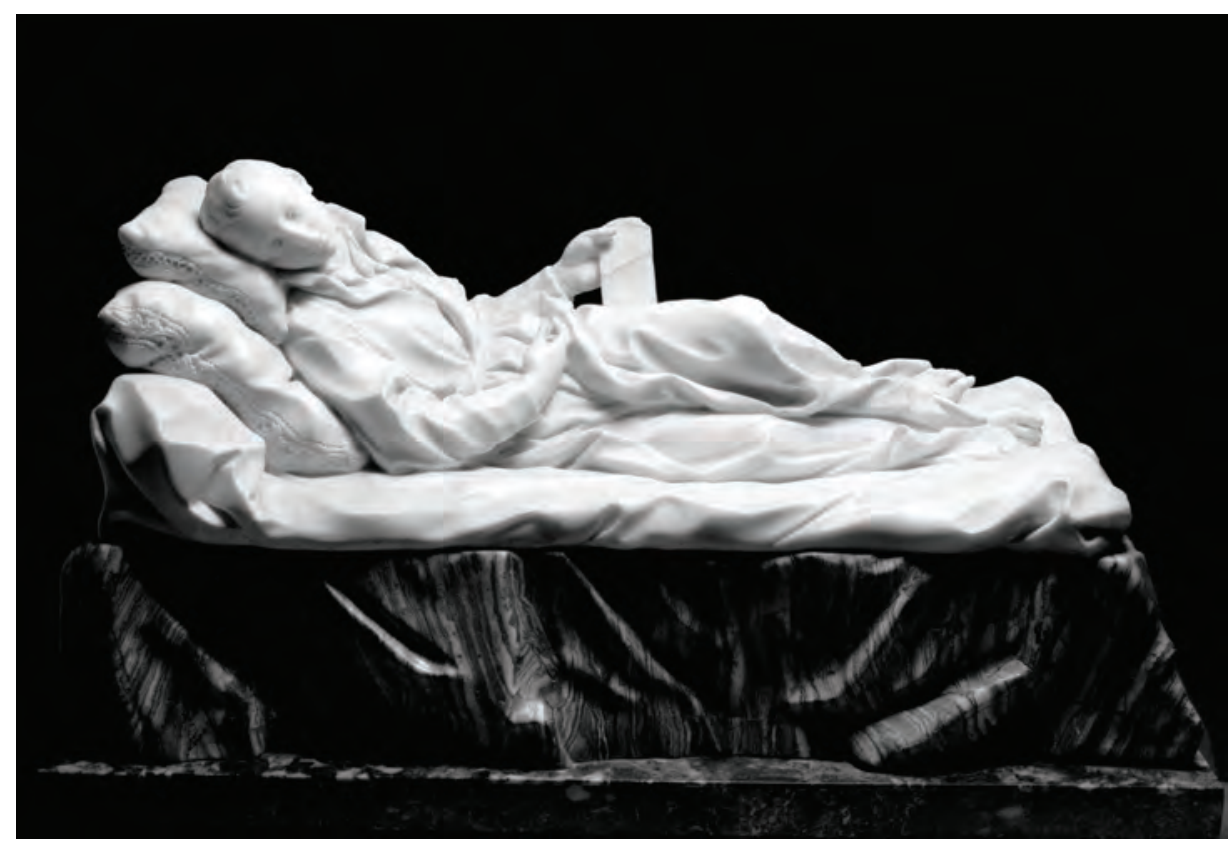

11. Figura św. Stanisława Kostki (bozzetto), warsztat P. Legros'a, 1703, Baseln Museum of Antiquities and Ludvig Collection, fot. www. http://baseljournal.ch/

i jego koncepcji wizji Marii przekazującej Dzieciątko św. Franciszkowi (kościół kapucynów w Antwerpii, 1614; kościół kapucynów w Lille, ok. 1617) w nawiązaniu do Liber conformitatum Bartolomea z Pizy ${ }^{48}$. Maria interpretowana być mogła zarówno jako Matka, jak i Virgo sacerdos, podająca, podobnie jak kapłan, mistyczne Ciało Chrystusa podczas mszy ${ }^{49}$.

W przedstawieniach Kostki najbardziej wymowną była jego pobożność, stanowiąca wzorcowy przykład głębokiego przeżycia emocjonalnego. Kardynał Robert Bellarmin pisał o nim, że „wylewał potoki łez gdy zostawał na modlitwie”, która była „nieprzerwanym ćwiczeniem miłości bardzo tkliwej”" ${ }^{50}$ a św. Franciszek Salezy w Traite de l'amour de Dieu dostrzegał duszę opanowaną miłością Boga, „iż z niej padał i mdlał" "51. Był to aspekt zrozumiały dla jak największej liczby widzów, bliski ignacjańskiej metodzie medytacji. Ludzie bowiem, jak zaznaczał Federico Borromeo, „ze swej natury i poprzez naturalny instynkt” odbierają precyzyjnie emocje obserwowanych przez siebie osób i ulegają ich nastrojom ${ }^{52}$. W intencji jezuitów ołtarz - w zależności od jego artystycznego wymiaru - był przede wszystkim obliczony na medialną dewocyjną skuteczność.

\footnotetext{
48 Tamże, s. 129-131, ilustr. 44 i 45.

49 Tamże, s. 129-131.

50 Bartoli 1670, s. 112; KoszUtski 1882, t. 1, s. 193.

51 Koszutski 1882, t. 1, s. 194.

52 Krasny 2010, s. 161; Borromeo 1994, s. 34 (przyp. 7).
} 


\section{Bibliografia}

\section{Źródła rękopiśmienne}

ARSI - Archivum Romanum Societatis Iesu.

BAV - Biblioteca Apostolica Vaticana.

BJ - Biblioteka Jagiellońska.

\section{Źródła drukowane i opracowania}

BAIley 2003 - Gauvin A. Bailey, Between Renaissance and Barock, Jesuit Art in Rom 1565-1610, Toronto 2003.

Bartoli 1670 - Daniel Bartoli, Della vita e miracoli del Beato Stanislao Kostka, Roma 1670.

Bell 2009 - Peter J. Bell, Greuter Johann Friedrich (Giovanni Federico), 1590-1662, [w:] Saur Allgemeines Künstler-Lexikon. Die Bildenden Künstler aller Zeiten und Völker, t. 61, MünchenLeipzig 2009.

Borremeo 1994 - Federico Borromeo, Della pittura sacra libri due, opr. B. Agosti, „Quaderni del Seminario di Storia della Critica d' Arte", 4 (1994).

Cereri 1994 - Giovanni Cereri, Bernini, Flight of Love, the Art of Devotion, Chicago 1994.

Chrzanowski/Kornecki 1994 - Tadeusz Chrzanowski, Marian Kornecki, Polskie pomniki w świqtyniach Rzymu, Warszawa 1994.

Conforti 1977 - Michael Conforti, Pierre Legros and the Rõle of Sculptors as Designers in late Baroque Rome, „The Burlington Magazine”, t. 119 (1977).

De Angelis 2003 - Maria Antonietta De Angelis, Ferri Ciro, [w:] Saur Allgemeines Kunstler-Lexikon. Die Bildenden Kunstler aller Zeiten und Völker, t. 39, München-Leipzig 2003.

Duryewski 1702 - Andrzej Duryewski, Pamiątka niezeszła już zeszłego domu jaśnie wielmożnych panów na Rostkowie i Sztembergu Kostkow, albo o niektórych z tej familiej płci oboiej, Kraków 1702.

ENGass 1976 - Robert Enggass, Early Eighteenth Century sculpture in Rome, University Park 1976.

GERKEN 2015 - Claudia Gerken, Entstehung und Funktion von Heiligenbildern im nachtridentinischen Italien (1588-1622), Petersberg 2015.

Gonzales-Palacios 2007 - Alvar Gonzales-Palacios, Il beato Stanislao Kostka e Pierre Legros, „Antologia di belle arti”, t. 67/70 (2007).

Haskell 1955 - Francis Haskell, Pierre Legros and a statue of the Blessed Stanislaw Kostka, „The Burlington Magazine”, t. 97 (1955), nr 9.

Hood 1979/80 - William Hood, Ciro Ferri's Pensiero for the Altarpiece of the Blessed Stanislaus Kostka in Sant' Andrea al Quirinale, „Allen Memorial Art Museum Bulletin”, t. 37 (1979-80).

Jaroszewicz 1850 - Florian Jaroszewicz, Matka świętych Polska albo żywoty Świętych, Błogosławionych, Wielebnych, Świątobliwych, pobożnych Polaków i Polek, Piekary Śląskie 1850.

Kerber 1971 - Bernhard Kerber, Andrea Pozzo, Berlin 1971.

KNAPIŃsKi 1999 - Ryszard Knapiński, Titulus ecclesiae. Ikonografia wezwań współczesnych kościołów katedralnych w Polsce, Warszawa 1999.

KöNIG-NordHOFF 1982 - Ursula König-Nordhoff, Ignatius von Loyola, Studien zur Entwicklung einer Heiligen-Ikonographie im Rahmen einer Kanonisationskampagne um 1600, Berlin 1982. 
Koszutski 1882 - Hilary Koszutski, Święty Stanisław Kostka, patron Królestwa Polskiego i jego wiek, t. 1 i 2, Poznań 1882.

KRASNy 2010 - Piotr Krasny, Visibilia signa ad pietatem excitantes. Teoria sztuki sakralnej w pismach pisarzy kościelnych epoki nowożytnej, Kraków 2010.

Leps 2015 - Sabrina Leps, Maratti (Maratta) Carlo, [w:] De Greyter Allgemeines Künstler-Lexikon. Die Bildenden Künstler aller Zeiten und Völker, t. 87, Berlin-Boston 2015.

LEvy 1997 - Evonne Levy, Reproduction in the "Cultic Era” of Art; Pierre Legros Statue of Stanislas Kostka, „Representations”, t. 58 (1997).

MАјкоwsкi 1965 - Józef Majkowski, Święty Stanisław Kostka. Studium z dziedziny hagiografii psychologicznej, Rzym 1965.

MARder 1998 - Tod A. Marder, Bernini and the Art of Architecture, New York-London-Paris 1998.

MĄCZYŃski 2003 - Ryszard Mączyński, Nowożytne konfesje polskie. Artystyczne formy gloryfikacji grobów świętych i błogosławionych $w$ dawnej Rzeczypospolitej, Torun 2003.

ОвоRsкі 1630 - Mikołaj S. Oborski, Relacya Abo Krótkie opisanie Cudów niektórych y dobrodzieystw przednieyßych, B. Stanisława Kostki Soc. Iesv: Ktoremi, na wzywanie pomocy iego, Pan Bog ludzi stanów wszelakich, cudownie w Królestwie tym pocieszyć raczył: Z Processow w Archidiecezyey Gnieźnieńskiey y Lwowskiey (...), Kraków 1630.

Pagaczewski 1927 - Julian Pagaczewski, Ze studiów nad ikonografią św. Stanisława Kostki, Kraków 1927.

Richeомe 1611 - Louis Richeome, La peinture spirituelle ou l'art d'admirer aimer et louer Dieu, Lyon 1611.

Royal Collection - dostęp online: www.royalcollection.org.uk [dostęp 1.01.2019].

Sacchini 1611 - Francesco Sacchini, Vita B. Stanislai Kostkae Poloni e Societate Jesu..., Ingolstadii 1611.

SAUERLÄNder 2011 - Willibald Sauerländer, Der katholische Rubens: Heilige und Märtyrer, München 2011.

SkARga 1936 - Piotr Skarga, Żywoty świętych Starego i Nowego Zakonu na każdy dzień przez cały rok..., t. 4, Kraków 1936.

Święty Stanisław Kostka 1928 - Święty Stanisław Kostka, opr. A. Ziemski, S. Bednarski, Warszawa 1928.

Sommervogel 1932 - Carlos Sommervogel SJ, Bibliotheque de la Compagnie de Jesus, t. 11, Brüssel-Paris 1932.

Terhalle 2011 - Johannes Terhalle, S. Andrea al. Quirinale von Gian Lorenzo Bernini in Rom. Von den Anfängen bis zur Grundsteinlegung, Weimar 2011.

UbALdini 1892 - Urbano Ubaldini, Vita et miracula S. Stanislai Kostka, [w:] Analecta Bollandiana, t. 11 (1892).

WARszawsKi 1968 - Józef Warszawski, Stanislao Kostka, w: Bibliotheca Sanctorum, t. 11, Roma 1968, szp. 1369-1373.

ZAZZARA 1962 - Francesco Zazzara, Diario delle onoranze a San Filippo dalla morte alla canonizazione, opr. Giovanni Incisa della Rocchetta, „Quaderni dell’ Oratorio”, 6 (1962). 


\section{A Painting or a Figure? Remarks on the Altar of Saint Stanislaus Kostka in the Church of Sant'Andrea al Quirinale in Rome}

$\mathrm{T}$

he Roman memorial altar devoted to Stanislaus Kostka (1550-1568), a Polish saint of international importance, was an exceptional example of how a modern reredos was constructed in the era of the counterreformation. Located in the Jesuit novitiate, the Church of Sant'Andrea al Quirinale is part of an unusual facility for the veneration of Kostka, which focuses on two separate entities - the chapel of the novitiate church and the monastic cell. The paper attempts to determine the role of the altar (which has undergone modifications and exhibits Kostka's effigy) as the most significant object of worship and liturgy. Three phases can be distinguished:

1) the first reredos, resembling an altar over the saint's grave, was constructed in about 1605 within the novitiate church of Sant'Andrea in Monte Cavallo, and rebuilt by the Jesuit Giovanni Tristano as a setting for Kostka's image,

2) a monumental altar in the oval space of the new novitiate church, designed by Gian Lorenzo Bernini (1658-1661), who wished to have a new and suitable altar painting, as evidenced by Ciro Ferri's design and several variants prepared by Carlo Maratta,

3) the modification of the altar related to the planned canonization - and following the rejection of the 1713 conception by the sculptor Legros - involved placing a figure of the dying Kostka and providing it with the backdrop of an altar painting.

As we learn from archival sources, a prerequisite for an artwork to be accepted and exhibited was that it should inspire piety and eschew 'devotionally ineffective' elements. This was because a painting was believed to play an important mediatory role, since it was more effective than a sculpture in arousing religious emotions. Kostka's charismatic piousness and his mystical sensations, regularly emphasised in the iconography, were a perfect example of deep emotional experience. According to Federico Borromeo, 'by nature and instinct', people can precisely sense the emotions of those they observe and can tune into their feelings. It was the Jesuits' intention for the altar to fulfil its medial devotional efficiency, through its artistic power. 